\title{
GAMBARAN PEMILIHAN ALAT KONTRASEPSI DAN TUJUAN KELUARGA BERENCANA PADA PASANGAN USIA SUBUR DI DUSUN GUNUNG KAWUNG DESA CIKUNIR KECAMATAN SINGAPARNA TAHUN 2017
}

\author{
ANNISA RAHMIDINI, SST, MKeb
}

\author{
Milan \\ annisarahmidini@gmail.com
}

STIKes Respati

\section{A. ABSTRAK}

Menurut Profil Kesehatan Indonesia tahun 2016 presentase KB aktif sebesar 74,8\% dan presentase KB tidak aktif sebesar 12,77\%. Berdasarkan laporan Puskesmas Singaparna tahun 2016 didapatkan data dari 10.675 pasangan usia subur, jumlah akseptor KB aktif adalah 7.954 atau $74,5 \%$. Tujuan dari penelitian ini adalah mengetahui jenis alat kontrasepsi dan tujuan KB yang digunakan oleh PUS di wilayah Dusun Gunung Kawung tahun 2017

Jenis penelitian yang digunakan adalah kuantitatif dengan metode deskristif. Populasi dalam penelitian ini adalah pasangan usia subur di wilayah Dusun Gunung Kawung yaitu 61 orang. Tehnik pengambilan sampling dalam penelitian ini adalah total sampling. Variabel dalam penelitian ini adalah jenis alat kontrasepsi dan tujuan KB. Instrumen yang digunakan adalah format isian yang tehnik pengambilan data penelitiannya dilakukan secara langsung terhadap responden. Analisis data yang digunakan adalah analisis univariat yang dihitung persentasenya kemudian disajikan dalam bentuk persentase dan naratif.

Hasil penelitian ini menunjukkan bahwa kontrasepsi hormonal suntik cenderung dipilih oleh karena kemudahan dalam menggunakan serta tujuan KB menjarangkan kehamilan. Petugas kesehatan dalam hal ini yang dimaksud adalah dokter spesialis kebidanan dan kandungan, dokter umum, bidan atau perawat memiliki peran serta dalam pemberian informasi, penyuluhan dan penjelasan mengenai alat kontrasepsi hormonal maupun non hormonal. Calon akseptor KB yang masih ragu dalam memakai alat kontrasepsi memutuskan memakai alat kontrasepsi non hormonal sesuai anjuran dari petugas dengan mempertimbangkan keuntungan dan kerugian dari alat kontrasepsi tersebut. Petugas kesehatan merupakan pihak yang mengambil peran dalam tahapan akhir proses pemakaian alat kontrasepsi

Kata Kunci Alat kontraseps, tujuan KB 


\section{B. LATAR BELAKANG}

International Conference on Population and Development(ICPD) pada tahun 1994 di Kairo telah merubah paradigma dalam pengelolaan masalah kependudukan, yang semula berorientasi kepada penurunan fertilitas (manusia sebagai obyek) menjadi pengutamaan kesehatan reproduksi perorangan dengan menghormati hak reproduksi setiap individu (manusia sebagai subyek). Program keluarga berencana memiliki makna yang sangat strategis, komprehensif dan fundamental dalam mewujudkan manusia Indonesia yang sehat dan sejahtera. UU Nomor 52 Tahun 2009 tentang perkembangan kependudukan dan pembangunan keluarga menyebutkan bahwa keluarga berencana adalah upaya untuk mengatur kelahiran anak, jarak, dan usia ideal melahirkan, mengatur kehamilan, melalui promosi, perlindungan, dan bantuan sesuai hak reproduksi untuk mewujudkan keluarga yang berkualitas.Terdapat tiga indikator tambahan yang berkaitan dengan KB dalam Millenium Development Goals(MDGs) 2015 target 5b (Akses Universal terhadap Kesehatan Reproduksi) yang diharapkan akan memberikan kontribusi dalam upaya peningkatan kesehatan ibu. Indikator tersebut adalah Contraceptive Prevalence Rate(CPR),Age Specific Fertility Rate(ASFR),dan unmet need. Target nasional indikator tersebut pada tahun 2015 adalah CPRsebesar 65\%, ASFRusia 15-19 tahun sebesar 30/1000 perempuan usia 1519 tahun dan unmet need $5 \%$. (Kemenkes RI, 2013)

$\begin{array}{lccr}\text { Program } & \text { Keluarga } & \text { Berencana } & (\mathrm{KB}) \\ \text { adalah } & \text { sarana } & \text { untuk } & \text { mencapai } \\ \text { penurunan } & \text { tingkat } & \text { kelahiran. } & \text { Menurut } \\ \text { Badan Koordinas Keluarga } & \text { Berencana } \\ \text { Nasional } & \text { /BKKBN } & (2005), & \text { sasaran } \\ \text { Program } & \text { Keluarga } & \text { Berencana } & \text { adalah }\end{array}$

Pasangan usia subur (PUS) yang mana pasangan suami istri yang istrinya berumur antara 15 sampai dengan 49 tahun atau pasangan suami-istri yang istri berumur kurang dari 15 tahun dan sudah haid atau istri berumur lebih dari 50 tahun, tetapimasih haid/datang bulan

Menurut Profil Kesehatan Indonesia tahun 2016 presentase KB aktif sebesar 74,8\% dan presentase $\mathrm{KB}$ tidak aktif sebesar 12,77\%. Berdasarkan laporan Puskesmas Singaparna tahun 2016 didapatkan data dari 10.675 pasangan usia subur, jumlah akseptor KB aktif adalah 7.954 atau 74,5\%. Selain itu berdasarkan wawancara dengan bidan puskesmas menyatakan bahwa dari 74,5\% tersebut masih terdapat PUS yang memilih alat kontrasepsi yang idak sesuai dengan tujuan KB misalnya PUS sudah berencana ingin mengakhiri masa kesuburan akan tetapi masih memilih alat kontrasepsi jangka pendek seperti suntik dan pil, hal ini disebabkan karena alat kontrasepsi tersebut membutuhkan biaya yang murah dan telah lama menggunakan alat kontrasepsi tersebut dengan efek samping yang tidak mengganggu kenyamanan mereka. Salah satu wilayah dengan partisipasi $\mathrm{Kb}$ yang rendah adalah Dusun Gunung Kawung dimana terdapat 61 orang $(60.6 \%)$ wanita usia subur yang berpartisipasi KB.

Berdasarkan hal tersebut, peneliti bermaksud untuk melakukan penelitian dengan judul "GAMBARAN PEMILIHAN ALAT KONTRASEPSI DAN TUJUAN KELUARGA BERENCANA PADA PASANGAN USIA SUBUR DI DUSUN GUNUNG KAWUNG DESA CIKUNIR KECAMATAN SINGAPARNA TAHUN 2017” 


\section{METODOLOGI PENELITIAN}

Jenis penelitian yang digunakan adalah kuantitatif dengan metode deskristif. Populasi dalam penelitian ini adalah pasangan usia subur di wilayah Dusun Gunung Kawung yaitu 61 orang. Tehnik pengambilan sampling dalam penelitian ini adalah total sampling. Variabel dalam penelitian ini adalah jenis alat kontrasepsi dan tujuan KB. Instrumen yang digunakan adalah format isian yang tehnik pengambilan data penelitiannya dilakukan secara langsung terhadap responden. Analisis data yang digunakan adalah analisis univariat yang dihitung persentasenya kemudian disajikan dalam bentuk persentase dan naratif.

\section{HASIL PENELITIAN}

1. Karakteristik responden

a. Usia responden

Tabel 1

Karakteristik responden berdasarkan usia pasangan usia subur di Dusun Gunung Kawung Desa Cikunir Kecamatan Singaparna Tahun 2017

\begin{tabular}{llll}
\hline Usia & & F & \% \\
\hline & kurang dari 20 tahun & 8 & 13.1 \\
\cline { 2 - 4 } & $20-35$ tahun & 42 & 68.9 \\
\cline { 2 - 4 } & lebih dari 35 tahun & 11 & 18.0 \\
\cline { 2 - 4 } Total & $\mathbf{6 1}$ & $\mathbf{1 0 0 . 0}$ \\
\hline
\end{tabular}

b. Pendidikan responden

Tabel 2

Karakteristik responden berdasarkan pendidikan pasangan usia subur di Dusun Gunung Kawung Desa Cikunir Kecamatan Singaparna

Tahun 2017

\begin{tabular}{lll}
\hline Tingkat pendidikan & F & \% \\
\hline tamat SD & 3 & 4.9 \\
\cline { 2 - 3 } tamat SMP & 22 & 36.1 \\
\hline tamat SMA & 36 & 59.0 \\
\hline Total & $\mathbf{6 1}$ & $\mathbf{1 0 0 . 0}$ \\
\hline
\end{tabular}

c. Pekerjaan responden

Seluruh responden tidak bekerja atau sebagai ibu rumah tangga 
2. Partisipasi PUS dalam keluarga berencana

Wanita usia subur yang ikut serta dalam program KB Dusun Gunung Kawung sebanyak 61 orang $(60.6 \%)$ dan Sebanyak 38 orang (39.4\%) wanita subur tidak ber-KB. Hasil wawancara dengan kader alasan wanita subur tidak menggunakan KB sebagian besar dikarenakan menginginkan mempunyai anak kembali.

3. Jenis alat kontrasepsi yang digunakan

\section{Tabel 3}

Karakteristik responden berdasarkan pendidikan pasangan usia subur di Dusun Gunung Kawung Desa Cikunir Kecamatan Singaparna Tahun 2017

\begin{tabular}{lll}
\hline Jenis alat kontrasepsi & F & \% \\
\hline pil & 46 & 75.4 \\
\hline suntik & 13 & 21.3 \\
\hline kondom & 1 & 1.6 \\
\hline IUD & 1 & 1.6 \\
\hline Total & $\mathbf{6 1}$ & $\mathbf{1 0 0 . 0}$ \\
\hline
\end{tabular}

Berdasarkan jenis KB yang digunakan di Dusun Gunung Kawung mayoritas menggunakan KB suntik sebanyak 46 orang (75.4\%).

4. Tujuan pemilihan alat kontrasepsi

\section{Tabel 4}

Karakteristik responden berdasarkan pendidikan pasangan usia subur di Dusun Gunung Kawung Desa Cikunir Kecamatan Singaparna Tahun 2017

\begin{tabular}{|c|c|c|}
\hline Tujuan KB & & \\
\hline & $\mathbf{F}$ & $\%$ \\
\hline menunda kehamilan & 9 & 14.8 \\
\hline menjarangkan kelahiran & 35 & 57.4 \\
\hline $\begin{array}{ll}\text { mengakhiri } & \text { masa } \\
\text { kesuburan } & \end{array}$ & 17 & 27.9 \\
\hline Total & 61 & 100.0 \\
\hline
\end{tabular}

Berdasarkan alasan menggunakan KB di Dusun Gunung Kawung sebanyak 28 orang (45.9\%) untuk menjarangkan kehamilan, sebanyak 18 oramg (29.5\%) menunda kehamilan dan sebanyak 15 orang $(24.6 \%)$ untuk mengakhiri kehamilan 


\section{Tabel 5}

Tabulasi silang tujuan KB dengan pemilihan alat kontrasepsi pasangan usia subur di Dusun Gunung Kawung Desa Cikunir Kecamatan Singaparna Tahun 2017

\begin{tabular}{|c|c|c|c|c|c|c|c|}
\hline & & & jenisal & & & & Total \\
\hline & & & pil & suntik & kondom & IUD & \\
\hline & & Count & 8 & 1 & 0 & 0 & 9 \\
\hline & menunda kehamilan & $\begin{array}{ll}\% & \text { within } \\
\text { tujuankb } & \end{array}$ & $88.9 \%$ & $11.1 \%$ & $0.0 \%$ & $0.0 \%$ & $100.0 \%$ \\
\hline & meniarangkan & Count & 29 & 4 & 1 & 1 & 35 \\
\hline tujuankb & $\begin{array}{l}\text { menjarangkan } \\
\text { kelahiran }\end{array}$ & $\begin{array}{ll}\% & \text { within } \\
\text { tujuankb } & \end{array}$ & $82.9 \%$ & $11.4 \%$ & $2.9 \%$ & $2.9 \%$ & $100.0 \%$ \\
\hline & menoakhiri & Count & 9 & 8 & 0 & 0 & 17 \\
\hline & $\begin{array}{l}\text { mengaknirı } \\
\text { kesuburan }\end{array}$ & $\begin{array}{ll}\% & \text { within } \\
\text { tujuankb } & \end{array}$ & $52.9 \%$ & $47.1 \%$ & $0.0 \%$ & $0.0 \%$ & $100.0 \%$ \\
\hline & & Count & 46 & 13 & 1 & 1 & 61 \\
\hline Total & & $\begin{array}{l}\% \\
\text { tujuankb }\end{array}$ & $75.4 \%$ & $21.3 \%$ & $1.6 \%$ & $1.6 \%$ & $100.0 \%$ \\
\hline
\end{tabular}

Berdasarkan tabel diatas didapatkan bahwa 8 orang $(88,9 \%)$ PUS yang bertujuan menunda kehamilan menggunakan alat kontrasepsi pil. Sedangkan 29 orang $(82,9 \%)$ pengguna alat kontrasepsi pil memiliki tujuan KB menjarangkan kehamilan serta $1(1,6 \%)$ pengguna IUD memiliki tujuan KB menakhiri masa kesuburan

\section{E. PEMBAHASAN}

Berdasarkan hasil penelitian didapatkan bahwa jenis alat kontrasepsi yang digunakan di Dusun Gunung Kawung mayoritas menggunakan $\mathrm{KB}$ suntik sebanyak 46 orang (75.4\%). Salah satu jenis kontrasepsi efektif yang menjadi pilihan kaum ibu adalah KB suntik, ini disebabkan karena aman, efektif, sederhana dan murah. Cara ini mulai disukai masyarakat dan diperkirakan setengah juta pasangan memakai kontrasepsi suntikan untuk mencegah kehamilan. Namun demikian KB suntik juga mempunyai banyak efek samping, seperti amenorea (30\%), spoting (bercak darah) dan menoragia, seperti halnya dengan kontrasepsi hormonal lainnya dan dijumpai pula keluhan mual, sakit kepala $(<1-17 \%)$, galaktorea $(90 \%)$, perubahan berat badan $(7-9 \%)$ (Hartanto, 2005 ).

Penggunaan kontrasepsi hormonal lebih banyak dibandingkan dengan kontrasepsi non hormonal yaitu sebanyak 59 orang (62.1\%). Penggunaan kontrasepsi hormonal masih memi-liki kecendrungan dengan penggunaan pil $\mathrm{KB}$, dan pada kontrasepsi non hormonal masih memi-liki kecendrungan untuk menggunakan jenis AKDR/IUD. Data tersebut sesuai dengan penelitian yang dilakukan oleh BKKBN. Prevalensi $\mathrm{KB}$ menurut alat $\mathrm{KB}$ dari peserta $\mathrm{KB}$ aktif di Indonesia tahun 2012 adalah $66,20 \%$, dimana alat $\mathrm{KB}$ yang dominan digunakan adalah KB hormonal, yaitu 
jenis sunti-kan sebanyak 34\% dan Pil KB sebanyak $17 \%$

Berdasarkan Profil Kesehatan Indonesia Tahun 2014, persentase peserta KB aktif menurut metode kontrasepsi di Indonesia yaitu suntikan $(47,54 \%)$, lalu pil $(23,58 \%)$, IUD $(11,07 \%)$, implant $(10,46 \%)$, kondom $(3,15 \%)$, Metoda Operasi Wanita atau MOW (3,52\%) dan Metoda Operasi Pria atau MOP sebanyak (0,69\%). Sedangkan pada peserta KB baru, persentase metode kontrasepsi yang terbanyak digunakan yaitu suntikan $(49,67 \%)$, pil $(25,14 \%)$, implan $(10,65 \%)$, IUD (7,15\%), kondom (5,68\%), MOW $(1,50 \%)$ dan MOP $(0,21 \%)$ (Kemenkes, 2015)

Berdasarkan tabel diatas didapatkan bahwa Pus yang bertujuan menunda kehamilan terdapat $11,1 \%$ masih menggunakan $\mathrm{KB}$ suntik, serta terdapat $52,9 \%$ akseptor $\mathrm{KB}$ yang bertujuan mengakhiri masa kesuburan masih menggunakan alat kontrasepsi metode jangka pendek seperti pil.

Pada penelitian ini, sebagian besar responden mengatakan alasan penggunaan kontrasepsi hormonal karena kemudahan menggunakannya, hal ini berkaitan dengan pemakian kontrasepsi hormonal yang bersifat praktis, mudah dijang-kau, murah dan efisien, dan beranggapan bahwa pemasangan AKDR menimbulkan rasa sakit. Minimalnya interaksi dengan petugas kesehatan menyebabkan informasi baik mengenai efek samp-ing maupun alternatif metode kontrasepsi lain yang di miliki oleh akseptor KB kurang. Sehingga hal tersebut menyebakan para akseptor tidak mempunyai pertimbangan dalam menggunakan KB hormonal

Sering kali Anggota keluarga, sanak saudara, teman dan tetangga berpengaruh dalam penggunaan metoda kontrasepsi, karena berbagi pengalaman atau menjadikan pengalaman orang lain sebagai acuan untuk menentukan pilihan metoda kontrasepsi yang akan digunakan. Pemberian informasi yang memadai mengenai efek samping alat kontrasepsi, juga akan membantu klien menentukan pilihan metode alternatif lain yang sesuai dengan kondisinya.

\section{F. KESIMPULAN DAN SARAN}

\section{Kesimpulan}

a) Berdasarkan jenis alat kontrasepsi yang digunakan di Dusun Gunung Kawung mayoritas menggunakan KB suntik sebanyak 46 orang $(75.4 \%)$.

b) Berdasarkan alasan menggunakan KB di Dusun Gunung Kawung sebanyak 28 orang (45.9\%) untuk menjarangkan kehamilan, sebanyak 18 oramg $(29.5 \%)$ menunda kehamilan dan sebanyak 15 orang (24.6\%) untuk mengakhiri kehamilan

\section{Saran}

Hasil penelitian ini menunjukkan bahwa kontrasepsi hormonal cenderung dipilih oleh karena kemudahan dalam menggunakan, dan kontrasepsi non hormonal cenderung dipilih oleh karena saran dari petugas kesehatan. Petugas kesehatan dalam hal ini yang dimaksud adalah dokter spesialis kebidanan dan kandungan, dokter umum, bidan atau perawat memiliki 
peran serta dalam pemberian informasi, penyuluhan dan penjelasan mengenai alat kontrasepsi hormonal maupun non hormonal. Calon akseptor $\mathrm{KB}$ yang masih ragu dalam memakai alat kontrasepsi memutuskan memakai alat kontrasepsi non hormonal sesuai anjuran dari petugas dengan mempertimbangkan keuntungan dan kerugian dari alat kontrasepsi tersebut. Petugas kesehatan merupakan pihak yang mengambil peran dalam tahapan akhir proses pemakaian alat kontrasepsi

\section{G. DAFTAR PUSTAKA}

Arliana, W, OD, Sarake, M, Seweng, A. 2013. Faktor yang Berhubungan dengan Penggunaan Metode Kontrasepsi Hormonal Pada Akseptor KB di Kelurah an Pasarwajo Kecamatan Pasarwajo Kabupaten Buton Sulawesi Tenggara. Sulawesi Tenggara : Universitas Hasanuddin

Badan Pusat Statistik (2011). Fertilitas Penduduk Indonesia Hasil Sensus Penduduk 2010, Jakarta.

Badan Pusat Statistik (2013). Survei Demografi dan Kesehatan 2012, Jakarta.

BKKBN. 2013. Laporan BKKBN tahun 2013. Jakarta: BKKB

Hartanto, H. 2010. Keluarga Berencana dan Kontrasepsi. Jakarta: Sinar Harapan.

Kemenkes. 2015. Rencana Strategis Kementerian Kesehatan Tahun 2015 -
2019. Jakarta: Kementerian Kesehatan RI

Kementerian Kesehatan. Laporan Nasional Riset Fasilitas Kesehatan 2011, Badan Litbang Kesehatan, Jakarta, 2012.

Kementerian Kesehatan. Laporan Riset

Kesehatan Dasar 2012, Badan Litbang Kesehatan, Jakarta 2013.

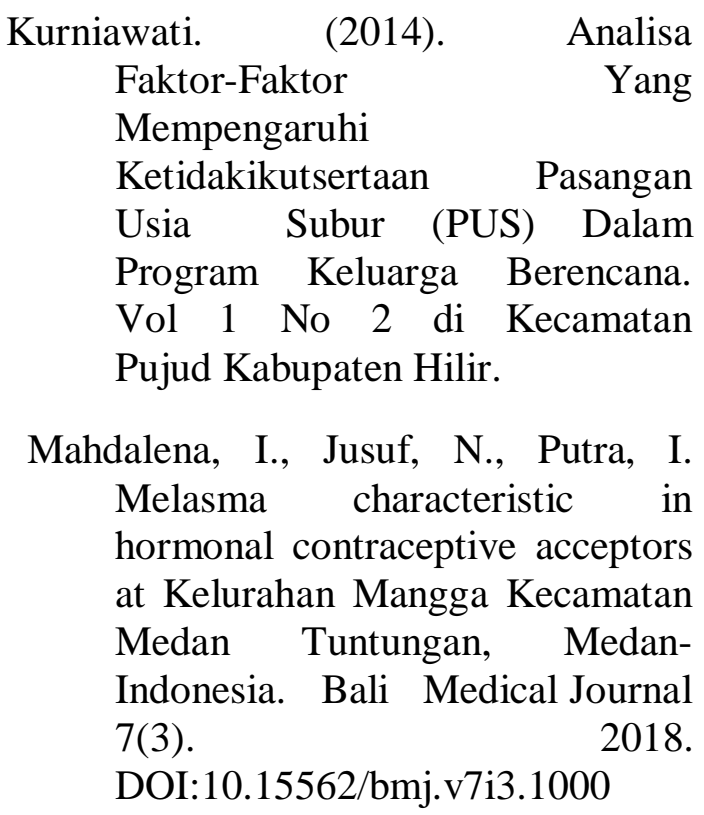

Manuaba dkk. (2009). Memahami Kesehatan ReproduksiWanita. Ed 2 Jakarta: EGC5.Notoatmodjo, Soekidjo. (2010). Metodologi Penelitian Kesehatan Edisi Revisi. Jakarta: Rineka Cipta

Population Reference Bureau. Family Planning Worldwide 2008 Data Sheet, Washington.

World Health Organization. World Health Statistics2013, Italia World Health Organization, 2013 